\title{
Corn husk extracts as an antioxidant additive in diets for Nile tilapia (Oreochromis niloticus) fingerlings: Effect on growth performance, feed intake and toxicity
}

Extractos de hoja de mazorca de maíz como aditivo antioxidante en dietas para juveniles de tilapia del Nilo (Oreochromis niloticus): Efectos sobre el crecimiento, el consumo de alimento y la toxicidad

\author{
José Andrés Galeana-López, Crisantema Hernández* , Nayely Leyva-López², Cynthia Esmeralda Lizárraga-Velázquez, \\ Erika Yazmín Sánchez-Gutiérrez', José Basilio Heredia ${ }^{3}$ \\ ${ }^{1}$ Laboratorio de Nutrición, Centro de Investigación en Alimentación y Desarrollo A.C., Unidad Mazatlán, Av. Sábalo Cerritos \\ s/n. Mazatlán, Sinaloa, 82112, México. \\ ${ }^{2}$ Cátedras CONACYT- Centro de Investigación en Alimentación y Desarrollo A.C. Unidad Mazatlán, Av. Sábalo Cerritos s/n. \\ Mazatlán, Sinaloa, 82112, México. \\ ${ }^{3}$ Laboratorio de Alimentos Funcionales y Nutracéuticos. Centro de Investigación en Alimentación y Desarrollo A.C., Unidad \\ Culiacán. Carretera Eldorado Km 5.5, Culiacán, Sinaloa, 80110, México.
}

\section{ABSTRACT}

Corn stover, a corn harvest by-product, can be used to add value to feeds for farmed fish through their extracts, which are rich in phenolic compounds (PCs) and could confer antioxidant properties and possible health benefits to fish. In this study, PCs from corn husk extracts (CHE) were identified by ultra-performance liquid chromatography-electrospray ionization-quadrupole time of fly-mass spectroscopy (UPLCESI-Q-ToF-MS/MS), and used to provide antioxidant potential to diets for Nile tilapia fingerlings. Three experimental diets for tilapia were formulated with 0, 100 and $200 \mathrm{mg}$ PCs from $\mathrm{CHE} / \mathrm{kg}$ feed and their antioxidant capacity was determined by DPPH• and ORAC assays. A total of 180 Nile tilapia fingerlings $(0.35 \pm 0.06 \mathrm{~g})$ were fed for 14 days to determine the effect of experimental diets on feed intake and growth performance. PCs from CHE such as ferulic, $p$-coumaric and chlorogenic acids were the most abundant. The inclusion of PCs into tilapia diets increases linearly $(p<0.05)$ their antioxidant capacity (DPPH and ORAC). Growth performance and feed intake increased linearly $(p<0.05)$ as the level of $\mathrm{CHE}$ inclusion increased. Results suggest that the CHE can provide antioxidant potential to tilapia diets, promote growth performance and feed intake without toxic effects.

Keywords: Phenolic compounds, antioxidants, tilapia, corn by-products.

\section{RESUMEN}

La mazorca de maíz, un subproducto de la cosecha de maíz, puede usarse para agregar valor a los alimentos para peces de cultivo a través de sus extractos, que son ricos en compuestos fenólicos (PCs) y los cuales podrían conferir propiedades antioxidantes y posibles beneficios a la salud de los peces. En este estudio, las PCs de los extractos de cáscara de maíz (CHE) se identificaron mediante cromatografía líquida de ultra resolución-tiempo de vuelo con cuadrupolo acoplado a espectrometría de masas con ionización por electrospray (UPLC-ESI-Q-ToF-MS/MS), y se utilizaron para

*Autor para correspondencia: Crisantema Hernández

Correo electrónico: chernandez@ciad.mx

Recibido: 8 de noviembre de 2019

Aceptado: 22 de enero de 2020 proporcionar potencial antioxidante a las dietas para alevines de tilapia del Nilo. Se formularon tres dietas experimentales para tilapia con 0, 100 y $200 \mathrm{mg}$ de PCs de CHE/kg de alimento y su capacidad antioxidante se determinó mediante ensayos DPPH - y ORAC. Se alimentaron un total de 180 alevines de tilapia del Nilo $(0.35 \pm 0.06 \mathrm{~g})$ durante 14 días para determinar el efecto de las dietas experimentales, sobre el consumo de alimento y el crecimiento. Los PCs de CHE como los ácidos ferúlico, $p$-cumárico y clorogénico fueron las más abundantes. La inclusión de PCs en las dietas para tilapia, aumenta linealmente ( $p<0.05$ ) su capacidad antioxidante (DPPH• y ORAC). El crecimiento y el consumo de alimento aumentaron linealmente $(p<0.05)$ a medida que aumentó el nivel de inclusión de $\mathrm{CHE}$. Los resultados sugieren que el $\mathrm{CHE}$ puede proporcionar potencial antioxidante a las dietas para tilapia y promover el crecimiento y el consumo de alimento de esta especie sin efectos tóxicos.

Palabras clave: Compuestos fenólicos, antioxidantes, tilapia, residuos de maíz.

\section{INTRODUCTION}

In Mexico, corn is the most cultivated crop with a production of more than 27.9 million tons in 2019 (SIAP, 2019). The grain is a rich source of carbohydrate and protein and is mainly used for human and farm animal consumption. The corn stover (leaves, stems, panicles, husk and cobs), which has a high fiber and low protein content, is commonly used to feed livestock during the cold season and as compost (Reyes et al., 2013). However, such by-products can be used to add value to diets of some animals, for instance in the aquaculture field.

Corn stover can be used as a source of PCs with antioxidant properties (Vazquez-Olivo, 2017). Among these PCs, hydroxycinnamic acids such as ferulic, $\rho$-coumaric, caffeic and sinapic acids are the most abundant. These types of plant metabolites participate as intermediates in the biosynthesis of lignin bound to cell wall components (Adom

Volumen XXII, Número 2 
and Liu, 2002). In corn, ferulic acid is the major phenolic compound and it is bound in grain cell walls. Nevertheless, corn husk has the highest concentration of PCs with ferulic and $\rho$-coumaric acids being the most abundant (Žilic》 et al., 2012; Vazquez-Olivo, 2017).

Hydroxycinnamic acids exert antioxidant effects such as free radical scavenging, metal chelation and modulation of enzymatic activity, which prevent metabolic and chronic diseases in mammals and other species (Ou and Kwok, 2004; Itagaki et al., 2009; Paiva et al., 2013; Pei et al., 2016; Zhu et al., 2018). Despite the potential effect of phenolic acids on the health status of organisms including humans, they have been associated with astringent and bitter flavors (Huang and Zayas, 1991), and they are highly susceptible to environmental factors such as intense lighting and high temperatures (Sohn and Oh, 2003; Arceusz et al., 2013; Makila et al., 2016).

In aquaculture, the use of PCs as feed additives has been implemented in order to favor the primary defense antioxidant system, resistance to oxidative stress and post-mortem muscle preservation, as well as to modulate beneficial microbial communities in the gut of farmed organisms (Gómez-Guillén and Montero, 2007; Giannenas et al., 2012; Maqsood et al., 2013; Magrone et al., 2016; Papuc et al., 2017; Sun et al., 2017; Oniszczuk et al., 2019; Lizarraga-Velázquez et al., 2019). Although PCs exert extensive antioxidant effects which have consequent health benefits, their inclusion in fish diets can modify feed intake, and have an impact on survival and growth performance of fish (El-Mesallamy et al., 2016; Omnes et al., 2017). Thus, given that the Nile tilapia (Oreochromis niloticus) is one of the most cultivated freshwater fish which can tolerate a multitude of environmental factors and exhibits a moderate protein requirement that can be derived from plant origin (Montoya-Camacho et al., 2019), it is a good model for the current study.

Therefore, the aim of this study was to characterize the PCs profile of CHE and determine their antioxidant capacity in vitro when added to fish diets, as well as to evaluate their effect on growth performance, feed intake and toxicity in Nile tilapia fingerlings.

\section{MATERIALS AND METHODS Extraction of PCs from corn husk}

Fresh corn husk was dried with forced air at $40^{\circ} \mathrm{C}$ during $24 \mathrm{~h}$ and ground to a particle size of $250 \mu \mathrm{m}$. PCs were extracted according to Adom and Liu (2002) with minor modifications. Fresh corn husk powder $(0.5 \mathrm{~g})$ was homogenized in $10 \mathrm{~mL}$ of $80 \%$ ethanol, and shaken in an Orbit Environ Shaker (Lab-Line, USA) at $200 \mathrm{rpm}$ for $12 \mathrm{~h}$ at room temperature. The mixture was centrifuged $(3000 \mathrm{~g}, 15 \mathrm{~min}, 4$ ${ }^{\circ} \mathrm{C}$ ) in an Allegra X-30R model A99470 centrifuge (Beckman Coulter, Germany), and the supernatant with the free PCs was collected and stored at $-20^{\circ} \mathrm{C}$ until use. The pellet was digested with $10 \mathrm{~mL}$ of $2 \mathrm{M}$ sodium hydroxide at $95^{\circ} \mathrm{C}$ for 30 min in order to extract bound PCs. Subsequently, samples were incubated at room temperature with shaking at 200 rpm during $1 \mathrm{~h}$. The mixture was neutralized with $2 \mathrm{~mL}$ of 37 $\% \mathrm{HCl}$ and $10 \mathrm{~mL}$ of hexane was used to remove lipids from the extract through centrifugation. The supernatant was removed, and the pellet was washed five times with $10 \mathrm{~mL}$ of ethyl acetate to drag PCs. Ethyl acetate was evaporated at $35^{\circ} \mathrm{C}$ under vacuum conditions and $\mathrm{PCs}$ were reconstituted with $2 \mathrm{~mL}$ of $80 \%$ ethanol and stored at $-20{ }^{\circ} \mathrm{C}$ until use. Supernatants stored were mixed to quantify the total PCs content.

\section{Quantification of total PCs}

Total PCs content was determined using the methodology described by Singleton et al. (1999); $10 \mu \mathrm{L}$ of each extract were diluted with $230 \mu \mathrm{L}$ of distilled water. Afterwards, $10 \mu \mathrm{L}$ of Folin-Ciocalteu reagent were added and the mix was incubated for $3 \mathrm{~min}$ in darkness, and then it neutralized with $25 \mu \mathrm{L}$ of sodium carbonate $4 \mathrm{~N}$. The samples were incubated for 120 min and measured at $725 \mathrm{~nm}$ in a Synergy ${ }^{\mathrm{TM}}$ HT microplate reader (Biotek, USA). Total PCs content was determined using gallic acid as standard. Results were reported as $\mathrm{mg}$ of gallic acid equivalent (mg GAE)/100 g of dry weight (DW). From the known concentration of total PCs, dilutions in concentrations of 100 and $200 \mathrm{mg}$ of PCs from CHE were prepared.

\section{PCs profile determination by UPLC-ESI-Q-ToF-MS/MS}

The PCs content of reconstituted free and bound solutions of $\mathrm{CHE}$ was determined through Ultra-Performance Liquid Chromatography (UPLC) using an ACQUITY UPLC; $\mathrm{H}$-Class system (Waters, Massachusetts, USA) coupled to a G2 XS Quadrupole-Time-of-Flight (Q-Tof) mass spectrometer (Agilent, California, USA) equipped with electrospray ionization (ESI). PCs were separated by UPLC at $40{ }^{\circ} \mathrm{C}$ with an ACQUITY BEH C18 $(1.7 \mu \mathrm{m}, 2.1 \times 50 \mathrm{~mm})$ column using a mobile phase composed of $0.1 \%$ formic acid (A) and acetonitrile (B) at a flow rate of $0.3 \mathrm{~mL} / \mathrm{min}$. The gradient procedure was as follows: $0 \mathrm{~min}, 95 \%(\mathrm{~A}) ; 5 \mathrm{~min}, 70 \%(\mathrm{~A}) ; 9 \mathrm{~min}, 30 \%(\mathrm{~A}) ; 14 \mathrm{~min}$, 0\% (A); $14.5 \mathrm{~min}, 0 \%(\mathrm{~A}) ; 15 \mathrm{~min}, 95 \%(\mathrm{~A}) ; 16 \mathrm{~min}, 95 \%(A)$. An electrospray source in negative mode was used to collect mass spectra under the following conditions: nitrogen gas; desolvation temperature, $350^{\circ} \mathrm{C}$; desolvation gas, $13.3 \mathrm{~L} / \mathrm{min}$; capillary voltage, $1500 \mathrm{~V}$; and fragmentor voltage, $30 \mathrm{~V}$. The standard solutions were injected in different concentrations to make the calibration curve. Linear regression was used to evaluate relationships of concentration vs area sum, under the same conditions for each analyzed sample. Compounds were quantified using caffeic, chlorogenic, $p$-coumaric, ferulic, p-hidroxybenzoic and sinapic acids, as well as rutin as standards.

\section{Experimental diets}

PCs from CHE were incorporated into Nile tilapia diets which were formulated with approximately equal amounts of crude proteins $(350 \mathrm{~g} / \mathrm{kg})$ and lipids $(100 \mathrm{~g} / \mathrm{kg})$ (Jauncey, 2000). A basal diet without PCs was formulated as 
previously described by Hernández et al. (2010) and denoted as Ex-0. Two basal diets were supplemented with 100 and 200 $\mathrm{mg}$ PCs/kg feed, which were denoted as Ex-100 and Ex-200, respectively. The dry ingredients (Table 1 ) were ground in a hammer mill to a particle size of $250 \mu \mathrm{m}$. Macronutrients (fish meal, soybean meal, wheat flour) were mixed in a Hobart mixer (model A-200, Ohio, USA); and the micronutrients (carboxymethyl cellulose, vitamin premix, mineral premix, and vitamin ()) were then added. Fish oil and soy lecithin were added to the mixture of macro and micronutrients. Finally, PCs from CHE were previously homogenized in warm water and added until a homogeneous mixture was obtained.

Diets were extruded by using the twin-screw extruder TSE 20/40 (Brabender, Germany) under the following conditions: $30,50,70,100,100,100{ }^{\circ} \mathrm{C}$ for each stage and 3.3 to 5.0 bar of pressure. Pellets were dried with forced air at 37

Table 1. Ingredients, proximate composition and phenolic content of experimental diets.

Tabla 1. Ingredientes, composición proximal y contenido fenólico de las dietas experimentales.

\begin{tabular}{|c|c|c|c|}
\hline \multirow{2}{*}{$\begin{array}{l}\text { Ingredients } \\
(\mathbf{g} / \mathbf{k g})\end{array}$} & \multicolumn{3}{|c|}{ Diet } \\
\hline & Ex-0 & Ex-100 & Ex-200 \\
\hline Fish meal (sardine) $^{\mathrm{a}}$ & 453.4 & 453.4 & 453.4 \\
\hline Fish oil $^{b}$ & 65 & 65 & 65 \\
\hline Soybean mealc & 120 & 120 & 120 \\
\hline Wheat flour ${ }^{b}$ & 350 & 349.9 & 349.8 \\
\hline Carboxymethyl cellulose ${ }^{b}$ & 1 & 1 & 1 \\
\hline Vitamin premix ${ }^{d}$ & 5 & 5 & 5 \\
\hline${ }^{*}$ Mineral premix ${ }^{d}$ & 5 & 5 & 5 \\
\hline${ }^{* *}$ Vitamin $C^{e}$ & 0.6 & 0.6 & 0.6 \\
\hline $\mathrm{CHE}^{f}$ & 0 & 0.1 & 0.2 \\
\hline \multicolumn{4}{|l|}{ Composition (g/kg) } \\
\hline Dry matter & 937.28 & 916.64 & 918.97 \\
\hline Crude protein & 358.60 & 356.50 & 355.60 \\
\hline Crude lipid & 95.00 & 94.00 & 109.60 \\
\hline Ash & 85.40 & 83.50 & 83.50 \\
\hline $\mathrm{NFE}^{\mathrm{g}}$ & 398.28 & 382.64 & 370.19 \\
\hline Total phenolic compounds & 0.00 & 0.016 & 0.081 \\
\hline
\end{tabular}

a Selecta de Guaymas, S.A de C.V, Guaymas, Sonora México.

b Droguería cosmopolita, S.A. de C.V. México, D.F., México.

'Proteínas marinas y agropecuarias S.A. de C.V., Guadalajara, Jalisco, México.

d Trout Nutrition México S.A. de C.V. (by cortesy). *Mineral premix composition: Manganese, 100.00 g; Magnesium, 45.00 g; Zinc, 160.00 g; Iron, 200.00 g; Copper, $20.00 \mathrm{~g}$; lodine, $5.00 \mathrm{~g}$; Selenium, $0.40 \mathrm{~g}$; Cobalt $0.60 \mathrm{~g}$. ${ }^{* *}$ Vitamin premix composition: Vitamin A, 2400 IU/g; Vitamin D3, $2250 \mathrm{UI} / \mathrm{g}$; Vitamin E, $160.00 \mathrm{~g}$; Vitamin K3, $8.00 \mathrm{~g}$; Thiamine B1, $20.00 \mathrm{~g}$; Riboflavin B2, 40 g; Pyridoxine B6, 16.00 g; Vitamin B12, 80.00 mg; Pantothenic acid, 60.00 g; Nicotinic Acid, $160.00 \mathrm{~g}$; Folic Acid, $4.00 \mathrm{~g}$; Biotin, $0.50 \mathrm{~g}$; Vitamin C, $100.00 \mathrm{~g}$; Choline $300.00 \mathrm{~g}$, Excipient $1046.85 \mathrm{~g}$.

e DSM Nutritional Products Mexico S.A. de C.V., El Salto, Jalisco, Mexico.

${ }^{f}$ Phenolic compounds from Corn hursk extract

${ }^{9}$ NFE (Nitrogen free extract) calculated by subtraction, 100-(crude protein + crude fat + moisture + ash + PCs).
${ }^{\circ} \mathrm{C}$ for $12 \mathrm{~h}$. Sieves were used to remove fine particles, and the pellets were manually reduced to a size of approximately $0.5 \mathrm{~mm}$. Pellets were kept in sealed labelled containers and maintained at $-20^{\circ} \mathrm{C}$ until use.

\section{Analysis of ingredients and diets}

The proximal chemical analysis of ingredients and diets was conducted by triplicate. Moisture (method 934.01), lipid (method 920.39), and ash (method 942.05) contents were determined using standard methods described in AOAC (2005). Moisture was determined using a Craft stove (Felisa, Jalisco, Mexico). Lipid content was analyzed using a micro Foss Soxtec Avanti 2050 Automatic System (Foss Soxtec, Hoganäs, Sweden) using petroleum ether as the extractor solvent. Ash content was determined gravimetrically by combustion in a muffle furnace (Fisher Scientific International, Inc. Pennsylvania, USA) at $550^{\circ} \mathrm{C}$ for $6 \mathrm{~h}$.

The crude protein level was determined by Dumas combustion method (Ebling, 1968) using a Flash 2000 CHN/O Elemental analyzer (Thermo Scientific, Milan, Italy).

The final concentration of PCs in the experimental diets was analyzed following the same methodology used for the extraction of free PCs from the corn husk (Adom and Liu, 2002). PCs content was determined with the Folin-Ciocalteu reagent as mentioned above.

\section{Antioxidant capacity from diets}

The antioxidant capacity of extruded diets was determined by the oxygen-radical absorbance capacity (ORAC) assay and the 2,2-diphenyl-1-picrylhydrazyl (DPPH•) antioxidant assay. The ORAC assay was performed according to Huang et al. (2002). Briefly, $25 \mu \mathrm{L}$ of extract were added to each plate, then $150 \mu \mathrm{L}$ of flourescein $0.96 \mu \mathrm{M}$ dispensed for reduction and induced by $50 \mu \mathrm{L}$ of peroxyl radical generator (2,2'-Azobis (2-amidinopropane) dihydrochloride, AAPH 95.8 $\mu \mathrm{M})$. Measurements were performed at $485 \mathrm{~nm}$ by excitation and $580 \mathrm{~nm}$ by emission for 70 min every 70 seconds at $37^{\circ} \mathrm{C}$, using a Synergy ${ }^{\mathrm{TM}}$ HT microplate reader (BioTek, USA).

The DPPH• radical scavenging capacity was determined according to Brand-Williams et al. (1995). In a 96-well microplate, $280 \mu \mathrm{L}$ of DPPH - reagent $(200 \mu \mathrm{M}$ in ethanol) were added to $20 \mu \mathrm{L}$ of the extract. The absorbance was recorded at $540 \mathrm{~nm}$. Results were expressed as mmol trolox equivalents (TE)/g of diet. Data are reported as mean \pm SD for at least three replications.

\section{Fish culture conditions and feeding}

All male tilapia fingerlings were produced in a commercial farm facility in the south of Sinaloa. The fish were acclimatized at the Finfish Hatchery, from the Research Center for Food and Development CIAD, Mazatlán Unit.

A total of 180 fish with a mean initial weight of 0.35 $\pm 0.06 \mathrm{~g}$ were evenly distributed into 12 tanks of $70 \mathrm{~L}$ capacity, whereby each tank consisted of 15 fish. A completely randomized experimental design with four replicates per treatment was used. Nile tilapias were fed to apparent sati- 
ety three times a day (9:00, 12:00 and 16:00 h) for 14 days to evaluate the toxicity of PCs from CHE and their possible effect on feed intake and growth performance (Ahmed et al., 2017). Daily feed intake was measured throughout the experimental period. Nile tilapias were maintained in a recirculation system which included a settling tank with dissolved oxygen $5.0 \pm 0.3 \mathrm{mg} / \mathrm{L}$ and a temperature of $27 \pm 0.5^{\circ} \mathrm{C}$ that was monitored with a dissolved oxygen meter (YSI, Ohio, USA); ammonia, nitrite and nitrate were evaluated daily with Insta-Test ${ }^{\circ}$ strips (LaMotte Company, Maryland, USA). 20\% of the water volume was replaced with fresh water every two days and maintained with natural photoperiod.

\section{Growth parameters and feed efficiency}

Once per week, fish were anaesthetized using a solution of clove oil $(0.5 \mathrm{~mL} / \mathrm{L})$ and weighed to calculate their mean body weight. The feed efficiency and growth of tilapias were monitored in terms of weight gain (WG), specific growth rate (SGR), feed intake (FI), feed conversion ratio (FCR) and survival $(S)$, according to the following formulas:

$$
\begin{aligned}
& \text { WG }(\%)=100 \times[(\text { final body weight }- \text { initial } \\
& \text { body weight)/initial body weight; } \\
& \text { SGR }(\% / \text { day })=[100 \times(\text { In (final mean body } \\
& \text { weight) - In (initial mean body } \\
& \text { weight))/number of days]; } \\
& \mathrm{FI}(\mathrm{mg} / \mathrm{fish})=\Sigma_{\mathrm{i}} 14[\text { (total feed consumption }) / \\
& \text { (number of fish)]/number of days; } \\
& \mathrm{FCR}=\text { feed intake/weight gain; } \\
& \mathrm{S}(\%)=\text { (final number of fish/initial } \\
& \text { number of fish) } x 100 \text {. }
\end{aligned}
$$

\section{Statistical analysis}

Data were subject to a test of normality (Kolmogorov-Smirnov test) and homogeneity of variance (Levene's test) before statistical analysis. The results were analyzed using one-way analysis of variance (ANOVA). Linear and quadratic effects due to PCs addition in diets were determined. All statistical procedures were conducted with IBM SPSS Statistics 25 program.

\section{RESULTS AND DISCUSSION PCs content in CHE}

The free PCs content from corn husk was $171.33 \pm$ $7.33 \mathrm{mg} \mathrm{GAE} / 100 \mathrm{~g}$, while that the bound PCs content was $1837.37 \pm 136.64 \mathrm{mg} \mathrm{GAE} / 100 \mathrm{~g}$. Vazquez-Olivo et al. (2017) reported a similar content of free PCs (144.45 mg GAE/100 g), but a lower bound PCs content (1276.49 mg GAE/100 g) than the value obtained in this study. The differences among results could be attributed to the pre and postharvest conditions, drying temperature used in corn husk, as well as the differences among extraction methods (Kalt, 2005; Tomsone et al., 2012).

\section{PCs profile of CHE by UPLC-ESI-Q-ToF-MS/MS}

Free and bound PCs of CHE are shown in Table 2. Chlorogenic acid was the most abundant component in the free PCs fraction constituting $101.54 \mu \mathrm{g} / \mathrm{g}$ of corn husk, while ferulic and $p$-coumaric acids were the main components of the bound PCs fraction (12934.05 and $5731.14 \mu \mathrm{g} / \mathrm{g}$ from corn husk, respectively). Vázquez-Olivo et al. (2017) also have indicated that ferulic and $p$-coumaric acids are the major bound

Table 2. Phenolic compounds of corn husk extract identified by UPLC-ESI-Q-ToF-MS/MS.

Tabla 2. Compuestos fenólicos en extracto de hoja de mazorca identificados por UPLC-ESI-Q-ToF-MS/MS.

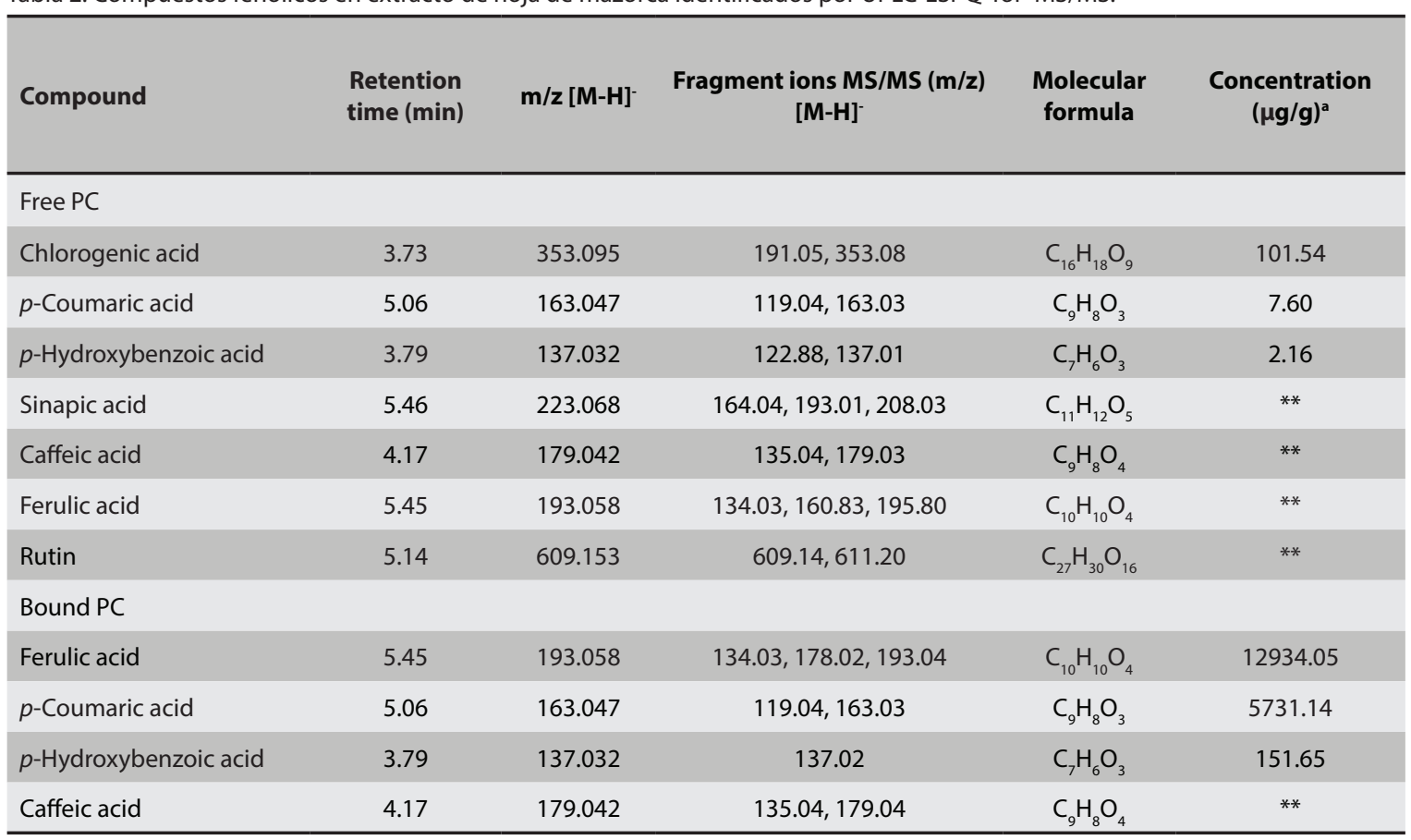

a Milligrams of phenolic compound per gram of corn husk dry matter. **Traces. 
PCs found in corn husk. However, these authors reported values of ferulic and $p$-coumaric acids (4555.00 and 3515.50 $\mu \mathrm{g} / \mathrm{g}$, respectively), which are lower than values obtained in our study. The results in both studies indicate that main PCs from corn husk are found bound to polysaccharides of the wall cell and lignin (Mounguengui et al., 2015).

\section{PCs content in experimental diets}

The concentration of PCs from experimental diets (Table 1) showed a reduction compared to the initial concentrations (100 and $200 \mathrm{mg}$ PCs/kg feed). The basal diet Ex-0 was adjusted to $0 \mathrm{mg} \mathrm{PCs} / \mathrm{kg}$, considering that it does not contain CHE. Therefore, the final concentrations of experimental diets were of $16.11 \mathrm{mg} \mathrm{PCs} / \mathrm{kg}$ for Ex-100 and 80.80 $\mathrm{mg} \mathrm{PCs} / \mathrm{kg}$ for Ex-200. The thermolability of PCs is one of the main drawbacks if they are outside of their natural matrix (for example bound to lignin), so despite the benefits of PCs, caution should be taken when integrating these compounds into diets (Ribas-Agustí et al., 2018). Our results suggest that the reduction of the PCs content in tilapia diets is due to the high temperatures used during the extrusion. Therefore, we consider that the use of PCs as fish feed additives with antioxidant properties, involves the optimization of the fish feed manufacturing process.

\section{Antioxidant capacity of experimental diets}

The use of extracts or meal from plants as feed additives for fish has intensified, due to their content of bioactive compounds such as PCs, which exhibit antioxidant properties (Catap et al., 2015; Villasante et al., 2015; LizárragaVelázquez et al., 2018; Lizárraga-Velázquez et al., 2019). Consequently, they could confer antioxidant capacity to the feed. In the present study, the antioxidant capacity measured by DPPH $\bullet$ and ORAC assays showed a linear increase $(p<0.05)$ according to the augmentation of PCs inclusion (Table 3). Previous studies have reported similar results in tilapia diets supplemented with plants as sources of natural antioxidants. Jiménez-Ruiz et al. (2019) indicated that dietary inclusion of avocado by-product paste increase the antioxidant capacity (DPPH.) of tilapia diets. In addition, the use of soybean meal and cottonseed meal as feed additives increase the DPPH. scavenging ability of tilapia diets (Lim and Lee, 2011). The increase in the antioxidant activity reported in these studies might be attributed to the bioactive compounds mix found in the plant matrix used. However, our results are mainly attributed to the presence of PCs such as ferulic and $p$-coumaric acids, since these are the major components in the CHE.

On the other hand, Table 3 shows that DPPH. scavenging ability showed values lower than antioxidant capacity measured by ORAC assay. The differences between the results of the two assays analyzed may be due to the different mechanisms of antioxidant action measured in each method. For example, DPPH• measures the ability of PCs to transfer electrons to free radicals, while ORAC assay is based on their hydrogen donating ability (Schaich et al., 2015). This indicate that the experimental diets have capacity to scavenge free
Table 3. Antioxidant capacity of experimental diets.

Tabla 3. Capacidad antioxidante de dietas experimentales.

\begin{tabular}{lccccccc}
\hline \multirow{2}{*}{ Assay } & \multicolumn{3}{c}{ Diet } & & \multicolumn{2}{c}{$\boldsymbol{P}$} \\
\cline { 2 - 4 } \cline { 7 - 8 } & Ex-0 & Ex-100 & Ex-200 & SEM & Linear & Quad \\
\hline \multirow{2}{*}{$\mathrm{DPPH} \cdot(\mathrm{mmol} \mathrm{TE} / \mathrm{g})^{\mathrm{a}}$} & 2.31 & 2.45 & 2.66 & 0.035 & $<0.001$ & 0.103 \\
& \pm 0.03 & \pm 0.05 & \pm 0.03 & & & \\
ORAC $(\mathrm{mmol} \mathrm{TE} / \mathrm{g})^{\mathrm{a}}$ & 4.24 & 4.31 & 4.36 & 0.015 & 0.001 & 0.021 \\
\hline
\end{tabular}

Values are mean $\pm \mathrm{SD}, \mathrm{n}=3$. ${ }^{\mathrm{a}} \mathrm{TE}=$ Trolox equivalents.

radicals through hydrogen atom donation. However, further investigation in fish in order to validate their antioxidant capacity in vivo is needed.

\section{Growth performance, feed intake, feed efficiency and survival}

Experimental diets were well accepted by tilapias throughout the entire experiment. Table 4 indicates that $\mathrm{FI}$ and growth performance parameters as FW, WG and SGR showed a linear increase $(p<0.05)$ as the level of PCs inclusion increased. Even though the FCR mean decreased as PCs incremented in the diets, this was not statistically significant. The survival percentage was not affected by increasing of PCs in diets.

The CHE contains PCs that can provide additional functional value to the tilapia diets. In this study, the addition of $200 \mathrm{mg} / \mathrm{kg}$ of CHE (Ex-200) resulted in the greatest increase in feed intake and growth performance (Table 4). Furthermore, a greater anticipatory activity to food was observed in fish fed with Ex-200 than in those fed with Ex-0 and Ex-100 diets. The diets were well tolerated, as demonstrated by the high feed intake, even when fish were apparently satiated, which might reflect a possible effect of the CHE on palatability.

Table 4. Growth parameters and feed efficiency of Nile tilapia fed experimental diets.

Tabla 4. Parámetros de crecimiento y eficiencia alimenticia de las tilapias del Nilo alimentadas con las dietas experimentales.

\begin{tabular}{|c|c|c|c|c|c|c|}
\hline \multirow{2}{*}{ Variable } & \multicolumn{3}{|c|}{ Diet } & \multirow[b]{2}{*}{ SEM } & \multicolumn{2}{|c|}{$P$} \\
\hline & Ex-0 & Ex-100 & Ex-200 & & Linear & Quad \\
\hline IW (g) & $\begin{array}{c}0.35 \\
\pm 0.06\end{array}$ & $\begin{array}{c}0.35 \\
\pm 0.06\end{array}$ & $\begin{array}{c}0.35 \\
\pm 0.06\end{array}$ & 0.00 & 0.177 & 0.380 \\
\hline $\mathrm{FW}(\mathrm{g})$ & $\begin{array}{c}0.94 \\
\pm 0.04\end{array}$ & $\begin{array}{c}0.99 \\
\pm 0.04\end{array}$ & $\begin{array}{c}1.03 \\
\pm 0.06\end{array}$ & 0.02 & 0.024 & 0.354 \\
\hline $\begin{array}{l}\mathrm{FI} \text { (mg/ } \\
\text { fish·day) }\end{array}$ & $\begin{array}{l}43.07 \\
\pm 0.24\end{array}$ & $\begin{array}{l}46.01 \\
\pm 0.93\end{array}$ & $\begin{array}{r}47.51 \\
\pm 0.83\end{array}$ & 0.55 & 0.004 & 0.043 \\
\hline WG (\%) & $\begin{array}{l}165.60 \\
\pm 5.62\end{array}$ & $\begin{array}{l}178.82 \\
\pm 5.01\end{array}$ & $\begin{array}{l}192.02 \\
\pm 8.25\end{array}$ & 6.29 & 0.023 & 0.355 \\
\hline SGR $(\% / d)$ & $\begin{array}{c}6.97 \\
\pm 0.15\end{array}$ & $\begin{array}{c}7.32 \\
\pm 0.13\end{array}$ & $\begin{array}{c}7.65 \\
\pm 0.20\end{array}$ & 0.16 & 0.022 & 0.340 \\
\hline FCR & $\begin{array}{c}1.00 \\
\pm 0.06\end{array}$ & $\begin{array}{c}1.01 \\
\pm 0.10\end{array}$ & $\begin{array}{c}0.97 \\
\pm 0.04\end{array}$ & 0.05 & 0.615 & 0.840 \\
\hline $\mathrm{S}(\%)$ & $\begin{array}{c}100 \\
\pm 0.00\end{array}$ & $\begin{array}{c}100 \\
\pm 0.00\end{array}$ & $\begin{array}{c}100 \\
\pm 0.00\end{array}$ & 0.00 & - & - \\
\hline
\end{tabular}

Values are mean $\pm S D, n=4$. IW=Initial weight; $F W=F i n a l$ weight; $F I=F e e d$ intake; WG=Weight gain; SGR=Specific growth rate; $F C R=F e e d$ conversion ratio; $\mathrm{S}=$ Survival. 
During the first month after hatching (part of the fingerling stage), Nile tilapias are highly susceptible to environmental factors that significantly affect survival, and feed intake is higher in relation to body weight (Gullian-Klanian and Arámburu-Adame, 2013). Therefore, the fingerling stage was selected to evaluate the difference in feed intake, changes in palatability and possible toxic effects of CHE in diets. Individually, the PCs of CHE have been evaluated in mammals and showed low toxicity. The OECD Guidelines for the Testing of Chemicals stablished that the maximum doses for oral administration of $p$-coumaric acid in experiments is $2000 \mathrm{mg} /$ $\mathrm{kg}$ body weight and with a known $\mathrm{LD}_{50}=2850 \mathrm{mg} / \mathrm{kg}$ for mice (Pei et al., 2016; Kim et al., 2017). In addition, dosage of 29.4 $\mathrm{mg} / \mathrm{kg}$ of ferulic acid in mice did not have negative effects (Hirabayashi et al., 1995).

In aquaculture, Magrone et al. (2016) reported that diets supplemented with $100-200 \mathrm{mg} / \mathrm{kg}$ of red grape seed extract (proanthocyanidins and catechins) had no toxic effect on sea bass (Dicentrarchus labrax L.). On the other hand, the dietary inclusion of 10 to $15 \mathrm{~g} / \mathrm{kg}$ of Roselle calyx extract, containing cyanidin, delphinidin, synergenic acid and ellagic acid as the most abundant PCs, enhanced growth performance and FI in Nile tilapia (El-Mesallamy et al., 2016). These results are consistent with a study by Yu et al. (2017) that also reported an increase in growth performance of tilapia juveniles fed with supplemented diets with $100 \mathrm{mg} /$ $\mathrm{kg}$ of ferulic acid. These data indicate that the effect of PCs on growth performance and FI might depend on their inclusion level and the difference in their phenolic profiles, as well as, the fish species and the species' feed preferences.

\section{CONCLUSIONS}

The inclusion of PCs from CHE increased the antioxidant capacity (DPPH and ORAC) of diets for Nile tilapia. Furthermore, the supplementation of 100 and $200 \mathrm{mg}$ PCs/ $\mathrm{kg}$ of $\mathrm{CHE}$ improved growth performance and feed intake without toxic effects in Nile tilapia fingerlings fed during 14 days. However, further studies are necessary to both support these findings and to probe the use of PCs from CHE as fish feed additives and their antioxidant effects in vivo on a large scale.

\section{ACKNOWLEDGEMENTS}

Funding was provided by Consejo Nacional de Ciencia y Tecnología (FORDECYT) grant 292474. This manuscript is part of the activities of the Thematic Network 12.3: to reduce and valorize the losses and the waste of food systems Project 294768. The authors are grateful to Contreras-Angulo Laura, Emus-Medina Alexis, Salazar-Reyes Vanessa for technical assistance and Dr. Berlanga-Reyes Cesar that provide statistical support.

\section{Author contributions:}

Conceived and designed the experiments: JAGL. The project was led by: $\mathrm{CH}$. Conducted bioassays: JAGL. Chemical assays collaboration by: JBH. The main manuscript was written by JAGL with input from CH, JBH, NLL, CELV and EYSG. All authors reviewed and approved of the final manuscript.

\section{REFERENCES}

Adom, K. K. and Liu, R. H. 2002. Antioxidant activity of grains. Journal of Agricultural and Food Chemistry. 50: 6182-6187.

Ahmed, M., Abdullah, N., Yusof, H. M., Shuib, A. S. and Razak, S. A. 2017. Improvement of growth and antioxidant status in Nile tilapia, Oreochromis niloticus, fed diets supplemented with mushroom stalk waste hot water extract. Aquaculture Research. 48: 1146-1157.

AOAC 2005. Official Methods of Analysis Washington, D.C, Association of Official Analytical Chemists.

Arceusz, A., Wesolowski, M. and Konieczynski, P. 2013. Methods for extraction and determination of phenolic acids in medicinal plants: a review. Natural Products Communications. 8: 1821-1829.

Brand-Williams, W., Cuvelier, M. E. and Berset, C. 1995. Use of a free radical method to evaluate antioxidant activity. LWT Food Science and Technology. 28: 25-30.

Catap, E. S., Jimenez, M. R. R. and Tumbali, M. P. B. 2015. Immunostimulatory and anti-oxidative properties of corn silk from Zea mays L. in Nile tilapia, Oreochromis niloticus. International Journal of Fisheries and Aquaculture. 7: 30-36.

El-Mesallamy, A., Ahmad, M., Souleman, A., El Morsy, A. and Abd El-Naby, A. 2016. Effects of Roselle calyx (Hibiscus sabdariffa L.)-supplemented diets on growth and disease (Aeromonas hydrophila) resistance in Nile tilapia (Oreochromis niloticus L.). Egyptian Pharmaceutical Journal. 15: 78-87.

Giannenas, I., Triantafillou, E., Stavrakakis, S., Margaroni, M., Mavridis, S., Steiner, T. and Karagouni, E. 2012. Assessment of dietary supplementation with carvacrol or thymol containing feed additives on performance, intestinal microbiota and antioxidant status of rainbow trout (Oncorhynchus mykiss). Aquaculture. 350-353: 26-32.

Gómez-Guillén, M. C. and Montero, M. P. 2007. Polyphenol uses in seafood conservation. American Journal of Food Technology, 2: 593-601.

Gullian-Klanian, M. and Arámburu-Adame, C. 2013. Performance of Nile tilapia Oreochromis niloticus fingerlings in a hyperintensive recirculating aquaculture system with low water exchange. Latin American Journal of Aquatic Research. 41: 150-162.

Hirabayashi, T., Ochiai, H., Sakai, S., Nakajima, K. and Terasawa, K. 1995. Inhibitory effect of ferulic acid and isoferulic acid on murine interleukin-8 production in response to influenza virus infections in vitro and in vivo. Planta Medica. 61: 221-6.

Huang, C. J. and Zayas, J. F. 1991. Phenolic Acid Contributions to Taste characteristics of corn germ protein flour products. Journal of Food Science. 56: 1308-1310.

Huang, D., Ou, B., Hampsch-Woodill, M., Flanagan, J. A. and Prior, R. L. 2002. High-throughput assay of oxygen radical absorbance capacity (ORAC) using a multichannel liquid handling system coupled with a microplate fluorescence reader in 96-Well format. Journal of Agricultural and Food Chemistry. 50: 4437-4444.

Itagaki, S., Kurokawa, T., Nakata, C., Saito, Y., Oikawa, S., Kobayashi, M., Hirano, T. and Iseki, K. 2009. In vitro and in vivo antioxidant properties of ferulic acid: A comparative study 
with other natural oxidation inhibitors. Food Chemistry. 114: 466-471.

Jauncey, K. 2000. Nutritional requirements. En: Tilapias: Biology and Exploitation Beveridge, M. C. M. and Mcandrew, B. J. (eds.). 327-375. Dordrecht: Springer Netherlands.

Jiménez-Ruíz, E. I., Rodríguez-Carpena, J. G., Hernández-Ortega, G. P., Sumaya-Martínez, M. T., Balois-Morales, R., SánchezHerrera, L. M. and Peraza-Gómez, V. P. 2019. Antioxidant properties of a tilapia (Oreochromis niloticus) diet with the inclusion of avocado by-product. Biotecnia. 21: 163-169.

Kalt, W. 2005. Effects of production and processing factors on major fruit and vegetable antioxidants. Journal of Food Science. 70: R11-R19.

Kim, D.-C., Kim, S., Hwang, K.-S. and Kim, C.-H. 2017. $p$-Coumaric acid potently down-regulates zebrafish embryo pigmentation: Comparison of in vivo assay and computational molecular modeling with phenylthiourea. Biomedical Science Letters. 23: 8-16.

Lim, S.-J. and Lee, K.-J. 2011. A microbial fermentation of soybean and cottonseed meal increases antioxidant activity and gossypol detoxification in diets for Nile tilapia, Oreochromis niloticus. Journal of the World Aquaculture Society. 42: 494503.

Lizárraga-Velázquez, C. E., Hernández, C., González-Aguilar, G. A. and Basilio-Heredia, J. 2018. Propiedades antioxidantes e inmunoestimulantes de polifenoles en peces carnívoros de cultivo. CienciaUAT. 12: 127-136.

Lizárraga-Velázquez, C. E., Hernández, C., González-Aguilar, G. A. and Heredia, J. B. 2019. Effect of dietary intake of phenolic compounds from mango peel extract on growth, lipid peroxidation and antioxidant enzyme activities in zebrafish (Danio rerio). Latin American Journal of Aquatic Research. 47: 602-611.

Magrone, T., Fontana, S., Laforgia, F., Dragone, T., Jirillo, E. and Passantino, L. 2016. Administration of a polyphenolenriched feed to farmed sea bass (Dicentrarchus labrax L.) modulates intestinal and spleen immune responses. Journal Oxidative Medicine and Cellular Longevity. 2016: 11.

Mäkilä, L., Laaksonen, O., Alanne, A.-L., Kortesniemi, M., Kallio, H. and Yang, B. 2016. Stability of hydroxycinnamic acid derivatives, flavonol glycosides, and anthocyanins in black currant juice. Journal of Agricultural and Food Chemistry. 64: 4584-4598.

Maqsood, S. and Benjakul, S. 2013. Effect of kiam (Cotylelobium lanceolatum (raib) wood extract on the haemoglobinmediated lipid oxidation of washed asian sea bass mince. Food and Bioprocess Technology. 6: 61-72.

Montoya-Camacho, N., Marquez-Ríos, E., Castillo-Yáñez, F. J., Cárdenas López, J. L., López-Elías, J. A., Ruíz-Cruz, S., JiménezRuíz, E. I., Rivas-Vega, M. E. and Ocaño-Higuera, V. M. 2019. Advances in the use of alternative protein sources for tilapia feeding. Reviews in Aquaculture. 11:515-526.

Mounguengui, S., Saha Tchinda, J.-B., Ndikontar, M. K., Dumarçay, S., Attéké, C., Perrin, D., Gelhaye, E. and Gérardin, P. 2016. Total phenolic and lignin contents, phytochemical screening, antioxidant and fungal inhibition properties of the heartwood extractives of ten Congo Basin tree species. Annals of Forest Science. 73: 287-296.

Omnes, M.-H., Le Goasduff, J., Le Delliou, H., Le Bayon, N., Quazuguel, P. and Robin, J. H. 2017. Effects of dietary tannin on growth, feed utilization and digestibility, and carcass composition in juvenile European seabass (Dicentrarchus labrax L.). Aquaculture Reports. 6: 21-27.

Oniszczuk, T., Oniszczuk, A., Gondek, E., Guz, L., Puk, K., Kocira, A., Kusz, A., Kasprzak, K. and Wójtowicz, A. 2019. Active polyphenolic compounds, nutrient contents and antioxidant capacity of extruded fish feed containing purple coneflower (Echinacea purpurea (L.) Moench.). Saudi Journal of Biological Sciences. 26: 24-30.

Ou, S. and Kwok, K. C. 2004. Ferulic acid: pharmaceutical functions, preparation and applications in foods. Journal of the Science of Food and Agriculture. 84: 1261-1269.

Paiva, L. B. d., Goldbeck, R., Santos, W. D. d. and Squina, F. M. 2013. Ferulic acid and derivatives: molecules with potential application in the pharmaceutical field. Brazilian Journal of Pharmaceutical Sciences. 49: 395-411.

Papuc, C., Goran, G. V., Predescu, C. N., Nicorescu, V. and Stefan, G. 2017. Plant polyphenols as antioxidant and antibacterial agents for shelf-life extension of meat and meat products: Classification, structures, sources, and action mechanisms. Comprehensive Reviews in Food Science and Food Safety. 16: $1243-1268$.

Pei, K., Ou, J., Huang, J. and Ou, S. 2016. p-Coumaric acid and its conjugates: dietary sources, pharmacokinetic properties and biological activities. Journal of the Science of Food and Agriculture. 96: 2952-2962.

Reyes, L., Camacho, T. and Guevara, F. 2013. Rastrojos: manejo, uso y mercado en el centro y sur de México. Aguascalientes, México: Instituto Nacional de Investigaciones Forestales, Agrícolas y Pecuarias. 7.

Ribas-Agustí, A., Martín-Belloso, O., Soliva-Fortuny, R. and ElezMartínez, P. 2018. Food processing strategies to enhance phenolic compounds bioaccessibility and bioavailability in plant-based foods. Critical Reviews in Food Science and Nutrition. 58: 2531-2548.

Schaich, K. M., Tian, X. and Xie, J. 2015. Reprint of "Hurdles and pitfalls in measuring antioxidant efficacy: A critical evaluation of ABTS, DPPH, and ORAC assays". Journal of Functional Foods. 18: 782-796.

SIAP 2019. Servicio de Información Agroalimentaria y Pesquera. [Consulted 01-14-2020]. Available at: http://infosiap.siap. gob.mx/

Singleton, V. L., Orthofer, R. and Lamuela-Raventós, R. M. 1999. [14] Analysis of total phenols and other oxidation substrates and antioxidants by means of folin-ciocalteu reagent. En: Methods in Enzymology. 152-178. Academic Press.

Sohn, Y.T. and Oh, J.H. 2003. Characterization of physicochemical properties of ferulic acid. Archives of Pharmacal Research. 26: 1002-1008.

Sun, J., Sun, L., Meng, Y., Yang, X. and Guo, Y. 2017. Antioxidant activities of young apple polyphenols and its preservative effects on lipids and proteins in grass carp (Ctenopharyngodon idellus) fillets. CyTA: Journal of Food. 15: 291-300.

Tomsone, L., Kruma, Z. and Galoburda, R. 2012. Comparison of different solvents and extraction methods for isolation of phenolic compounds from horseradish roots (Armoracia rusticana). International Journal of Agricultural Biosystems Engineering. 6: 236-241.

Vazquez-Olivo, G., López-Martínez, L. X., Contreras-Angulo, L. and Heredia, J. B. 2019. Antioxidant capacity of lignin and phenolic compounds from corn stover. Waste and Biomass Valorization. 10: 95-102. 
Villasante, A., Patro, B., Chew, B., Becerra, M., Wacyk, J., Overturf, K., Powell, M. S. and Hardy, R. W. 2015. Dietary intake of purple corn extract reduces fat body content and improves antioxidant capacity and n-3 polyunsaturated fatty acid profile in plasma of rainbow trout, Oncorhynchus mykiss. Journal of the World Aquaculture Society. 46: 381-394.

Yu, L.-J., Wu, F., Jiang, M., Yang, C.-G., Liu, W., Tian, J., Lu, X. and Wen, H. 2017. Ferulic acid: A natural compound as an efficient feed additive for GIFT (Oreochromis niloticus). Aquaculture Nutrition. 24: 27-35.
Zhu, H., Liang, Q.-h., Xiong, X.-g., Wang, Y., Zhang, Z.-h., Sun, M.-j., Lu, X. and Wu, D. 2018. Anti-inflammatory effects of $p$-coumaric acid, a natural compound of Oldenlandia diffusa, on arthritis model rats. Evidence-Based Complementary and Alternative Medicine. 2018: 9.

Žilić, S., Serpen, A., Akıllığlu, G., Gökmen, V. and Vančetović, J. 2012. Phenolic compounds, carotenoids, anthocyanins, and antioxidant capacity of Colored Maize (Zea mays L.) Kernels. Journal of Agricultural and Food Chemistry. 60: 1224-1231. 